Aksiologiya: Jurnal Pengabdian Kepada Masyarakat

Vol.5, No. 2, Mei 2021 Hal 203 - 208

ISSN 2528-4967 (print) dan ISSN 2548-219X (online)

\title{
Peningkatan Produktivitas Pupuk Kompos Bioaktivator dengan Bahan Baku Limbah Organik Rumah Tangga
}

\author{
Mellyta Uliyandari ${ }^{1}$, Emilia Candrawati ${ }^{2}$, Nurlia Latipah $^{3}$ \\ ${ }^{1,2}$ Prodi Pendidikan IPA FKIP Universitas Bengkulu \\ ${ }^{3}$ Prodi Tadris IPA IAIN Bengkulu \\ Email: mellytauliyandari@unib.ac.id ${ }^{1}$, \\ emiliacandrawati@unib.ac.id²,nurlialatipah@iainbengkulu.ac.id
}

\begin{abstract}
ABSTRAK
Pertanian yang ramah lingkungan masih menjadi prioritas bagi pemerintah daerah dalam pembangunan berkelanjutan karena diharapkan dapat meningkatkan dan mempertahankan produktivitas tinggi dalam bidang pertanian. Pengabdian ini dilakukan dengan tujuan untuk mewujudkan pertanian ramah lingkungan dengan memanfaatkan limbah organik rumah tangga sebagai bahan baku pembuatan kompos dengan Biokativator. Sasaran kegiatan dalam pengabdian ini adalah Kelompok Wanita Tani (KWT) Nila 4A, KWT Nila 6E dan KWT Lahan Hijau di RT.4 RW.01 Kelurahan Sumber Jaya Kecamatan Kampung Melayu Kota Bengkulu dengan jumlah sasaran sebanyak 45 orang. Metode yang digunakan dalam pengabdian ini terdiri dari 4 tahapan yaitu, tahap observasi, tahap penyuluhan, tahap monitoring, dan tahap evaluasi. Hasilnya adalah pupuk kompos yang dihasilkan cukup bagus, tidak ada ulat atau belatung, serta tidak terlalu bau., pupuk kompos dengan karakteristik demikian sangat cocok untuk diaplikasikan pada pertanian. Selain pupuk daun, dari kegiatan ini juga dihasilkan pupuk cair organik yang merupakan sisa cairan dari proses pembuatan pupuk kompos dengan bioaktivator. Setelah kegiatan ini KWT Nila 4A, KWT Nila 6E dan KWT Lahan Hijau di RT.4 RW.01 Kelurahan Sumber Jaya Kecamatan Kampung Melayu Kota Bengkulu diharapkan dapat membuat kompos bioaktivator dengan kualitas bagus dan berdaya jual tinggi.
\end{abstract}

Kata Kunci: bioaktivator; limbah organik rumah tangga; pupuk kompos.

\section{Increasing the Productivity of Bioactivator Compost with Organic Household Waste Raw Materials}

\section{ABSTRACT}

Environmentally friendly agriculture is still a priority for local governments in sustainable development because it is expected to increase and maintain high productivity in agriculture. This service was carried out with the aim of realizing environmentally friendly agriculture by utilizing household organic waste as raw material for composting with biocativators. The targets of this service are the Women Farmers Group (KWT) Nila 4A, KWT Nila 6E and KWT Green Land in RT.4 RW.01 Kelurahan Sumber Jaya Sub-district Kampung Melayu Bengkulu City with a total target of 45 people. The method used in this service consists of 4 stages, namely, the observation stage, the counseling stage, the monitoring stage, and the evaluation stage. The result is that the compost produced is quite good, there are no caterpillars or maggots, and does not smell too much. Compost with these characteristics is very suitable for application in agriculture. Apart from foliar fertilizers, this activity also produces organic liquid fertilizer, which is the residual liquid from the compostmaking process using a bioactivator. After this activity, KWT Nila 4A, KWT Nila $6 E$ and KWT Green Land at RT.4 RW.01 Kelurahan Sumber Jaya Sub-district Kampung Melayu City Bengkulu City are expected to be able to make bioactivator compost with good quality and high selling power.

Keywords: bioactivator; household organic waste; compost. 


\section{PENDAHULUAN}

Pertanian yang ramah lingkungan masih menjadi prioritas bagi pemerintah daerah dalam pembangunan berkelanjutan. Hal ini bertujuan untuk meningkatkan dan mempertahankan produktivitas tinggi yang memperhatikan pasokan hara organik, minimalisasi penggunaan pupuk anorganik, perbaikan biota tanah, pengendalian organisme pengganggu tanaman (OPT) secara alami, dan diversifikasi tanaman (Wihardjaka, 2018).

Pertanian ramah lingkungan ini sebenarnyatelahditerapkandiberbagai daerah di Indonesia, meski masih ada daerah yang belum menerapkan sistem pertanian ini. Ketergantungan terhadap pupuk kimia makin tinggi, hal ini disebabkan karena biaya pembelian pupuk organik yang cukup mahal (Santoso, 2015).

Salah satu daerah dengan sistem pertanian yang masih menggunakan pupuk anorganik terdapat di Kelurahan Sumber Jaya Kecamatan Kampung Melayu Kota Bengkulu. Di daerah itu, tanaman hortikultura mendominasi budidaya pertanian. Petani di Kelurahan Sumber Jaya lebih memilih menggunakan pupuk anorganik seperti Urea, ZA, dan NPK untuk memberikan nutrisi kepada tanaman budidaya. Permasalahannya, penggunaan pupuk anorganik/ kimia berkadar tinggi dapat mencemari tanah hingga merusak sistem ekologi tanah.

Bioteknologi pertanian yang dapat membantu petani memenuhi kebutuhan nutrisi tanaman diharapkan dapat diimplementasikan untuk mengatasi ketergantungan terhadap penggunaan pupuk anorganik. Salah satu cara yang dapat dilakukan adalah dengan memanfaatkan limbah/ sampah organik rumah tangga yang jumlahnya cukup banyak dan tidak termanfaatkan dengan baik sebagai pupuk kompos bagi tanaman.

Limbah adalah sisa dari suatu usaha maupun kegiatan yang mengandung bahan berbahaya atau beracun yang karena sifat, konsentrasi, dan jumlahnya, baik yang secara langsung maupun tidak langsung dapat membahayakan lingkungan, kesehatan, kelangsungan hidup manusia dan makhluk hidup lainnya (Putri, 2016). Bahan yang sering ditemukan dalam limbah antara lain senyawa organik yang dapat terbiodegradasi, senyawa organikyang mudah menguap, senyawa organik yang sulit terurai (Rekalsitran), logam berat yang toksik, padatan tersuspensi, nutrien, mikrobia patogen, dan parasit (Waluyo, 2010).

Berdasarkan asalnya, limbah/ sampah padat dapat digolongkan menjadi 2 (dua) yaitu sebagai berikut

Sampah organik, adalah sampah yang dihasilkan dari bahan-bahan hayati yang dapat didegradasi oleh mikroba atau bersifat biodegradable.

Sampah anorganik adalah sampah yang dihasilkan dari bahanbahan non hayati, baik berupa produk sintetik maupun hasil proses teknologi pengolahan bahan tambang. (Dahruji $\mathrm{dkk}, 2017)$.

Limbah organik adalah limbah yang dihasilkan dari bahan-bahan 
hayati yang dapat didegradasi oleh mikroba atau bersifat biodegradable. Limbah organik ini dapat diuraikan dengan mudah melalui proses alami. Beberapa jenis limbah yang termasuk ke dalam jenis limbah organik adalah limbah dari dapur, sisa-sisa makanan, pembungkus (selain kertas, karet dan plastik), tepung,sayuran, kulit buah, daun dan ranting.

Salah satu cara mewujudkan pertanian yang ramah lingkungan dan juga mengurangi kapasitas limbah adalah dengan pengomposan. Pengomposan merupakan proses dekomposisi terkendali secara biologis terhadap sampah padat organik dalam kondisi aerobik ataupun anaerobik (Suatanti \& Widyaningrum, 2017). Pengomposan secara alami membutuhkan waktu berkisar 6 bulan, namun dengan pemberian bioaktivator, pengomposan dapat berlangsung 2-3 minggu(Darmawati,2015). Bioaktivator dalam proses pengomposan yang banyak dipasarkan salah satunya yakni Effective Microorganism 4 (EM4). Mikroorganisme yang terdapat dalam EM4 terdiri dari Lumbricus (bakteri asam laktat) serta sedikit bakteri foto sintetik, Actinomycetes, Streptomyces sp.,dan ragi. Dengan menggunakan EM4, proses pengomposan dapat berlangsung selama 20 hari (Sahwan dkk, 2011). EM4 dapat digunakan untuk pengomposan, karena mampu mempercepat proses dekomposisi sampah organik (Pandebesie \& Rayuanti, 2013).

Secara umum ada beberapa faktor yang mempengaruhi pengomposan yaitu 1) Pemisahan bahan : bahanbahan yang sekiranya lambat atau sukar untuk didegradasi/diurai, harus dipisahkan/diduakan, 2) Bentuk bahan : semakin kecil dan homogen bentuk bahan, semakin cepat dan baik pula proses pengomposan. 3) Nutrien : untuk aktivitas mikroba di dalam tumpukan sampah memerlukan sumber nutrien Karbohidrat, misalnya antara 20\% - 40\%, 4) Kadar air optimum di dalam pengomposan bernilai antara $50-70 \%$ (Nunik \& Arini, 2018).

Berdasarkan permasalahan di atas maka perlu diberikan pengetahuan dan pelatihan kepada KWT Nila 4A, KWT Nila 6E, dan KWT Lahan Hijau di RT.4 RW.01 Kelurahan Sumber Jaya Kecamatan Kampung Melayu Kota Bengkulu tentang pembuatan kompos dengan pemberian bioaktivator EM4 untuk mengubah limbah organik rumah tangga menjadi pupuk kompos. Hal ini dikarenakan cara ini cukup mudah sehingga petani dapat melakukan kegiatan ini secara mandiri dan berkelanjutan.

\section{METODE PENELITIAN} Waktu dan Tempat Pelaksanaan

Pengabdian ini dilakukan pada pada tanggal 30 September 2019 di Balai Pertemuan Kelurahan Sumber Jaya

Metode pelaksanaan dalam kegiatan pengabdian ini terdiri dari empat tahapan, yakni:

\section{Tahap Observasi}

Pada tahap ini dilakukan wawancara dengan para peserta (KWT Nila 4A, KWT Nila 6E, dan KWT Lahan Hijau di RT.4 RW.01 Kelurahan Sumber Jaya Kecamatan Kampung 
Melayu Kota Bengkulu) untuk mengetahui jenis pupuk yang biasa mereka pakai dan sejauh mana pemahaman mereka tentang kompos bioaktivator.

2. Penyuluhan dan praktek terbimbibing

Peserta diberikan pengetahuan tentang teknik pembuatan pupuk kompos dari limbah organik rumah tangga dengan pemberian bioaktivator EM4. Pada tahapan ini juga peserta diajak untuk mempraktekkan secara langsung cara pembuatan pupuk kompos dari limbah organik rumah tangga dengan pemberian bioaktivator EM4 dengan bimbingan dari tim fasilitator (tim pengabdian).

3. Tahap Monitoring

Tahap ini dilakukan untuk mengetahui sejauh mana proses pembuatan kompos berlangsung, dengan melihat hasil dari proses pengomposan setelah dilakukan fermentasi selama 20 hari.

\section{Tahap Evaluasi}

Tahap evaluasi dilakukan dengan mengevalusi secara keseluruhan hasil yang didapat dan melakukan diskusi lanjutan dengan kelompok-kelompok KWT, guna membahas hal-hal yang belum jelas seputar pembuatan kompos dengan Bioaktivator.

\section{HASIL DAN PEMBAHASAN}

Pelatihan ini bertujuan untuk memberikan pengetahuan dan keterampilankepadaKelompokWanita Tani (KWT) Nila 4A, KWT Nila 6E, dan KWT Lahan Hijau RT. 4 RW.01
Kelurahan Sumber Jaya Kecamatan Kampung Melayu Kota Bengkulu dalam membuat pupuk kompos yang berasal dari limbah organik rumah tangga dengan pemberian bioaktivator EM4.

Pada tahap ini, peserta penyuluhan diberikan informasi dan pengetahuan tentang jenis kompos, manfaat dan proses pembuatannya. Selain itu, peserta juga dikenalkan alat dan bahan yang akan digunakan dalam membuat pupuk kompos dari limbah organik rumah tangga. Adapun alat yang digunakan antara lain ember dan tutupnya, pengaduk, gelas bekas air mineral, gelas ukur plastik, pisau,dan talenan sedangkan bahan yang digunakan antara lain sayuran yang merupakan limbah rumah tangga, air, dan bioaktivator EM4. Selama kegiatan penyuluhan, pengabdi memberikan kesempatan kepada peserta untuk bertanya.

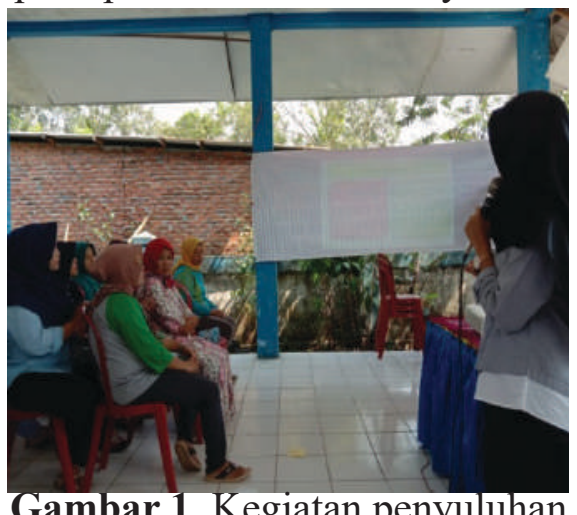

Gambar 1. Kegiatan penyuluhan

Tahap berikutnya adalah pelatihan sekaligus praktek terbimbing. Pada tahap ini, peserta langsung praktek membuat pupuk kompos dengan dibimbing oleh pengabdi. Peserta terlihat sangat antusias mengikuti kegiatan pelatihan dan praktek terbimbing. Usai praktek 
membuat pupuk kompos, ember yang Di dalamnya sudah terdapat bahan sayur yang dicampur bioaktivator EM4 ditutup, kemudian dibawa ke sekretariat KWT Nila IVA. Proses fermentasi pupuk kompos ini diperkirakan selama 20 hari.

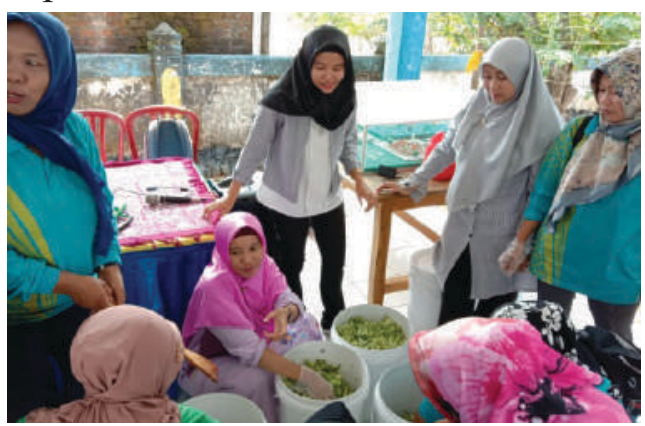

Gambar 2. praktek terbimbing pembuatan pupuk kompos kepada anggota KWT Nila 4A

Tahap monitoring dilakukan pada 21 Oktober 2019. Monitoring ini dilakukan setelah fermentasi pupuk kompos selesai. Tim pengabdi mengunjungi sekretariat KWT untuk melihat pupuk kompos yang dihasilkan. Hasil yang diperoleh pupuk kompos yang dihasilkan cukup bagus, tidak ada ulat atau belatung, serta tidak terlalu bau. Selain pupuk daun, dihasilkan juga pupuk cair organik dari proses tersebut, atau dalam hal ini kita kenal dengan pupuk cair organik.

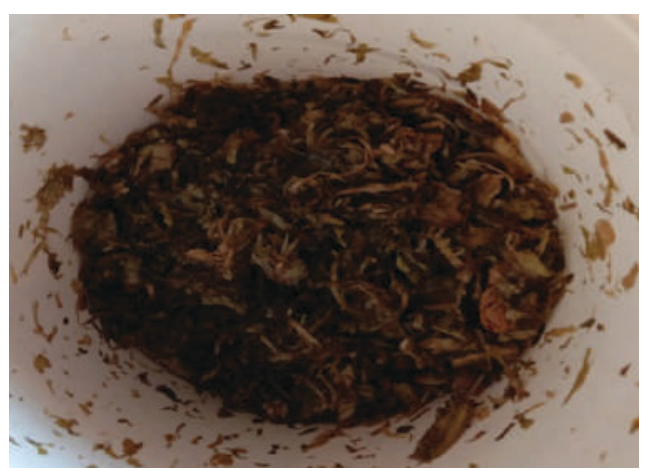

Gambar 3. Pupuk kompos berbahan dasar limbah organik rumah tangga dengan bioaktivator EM4

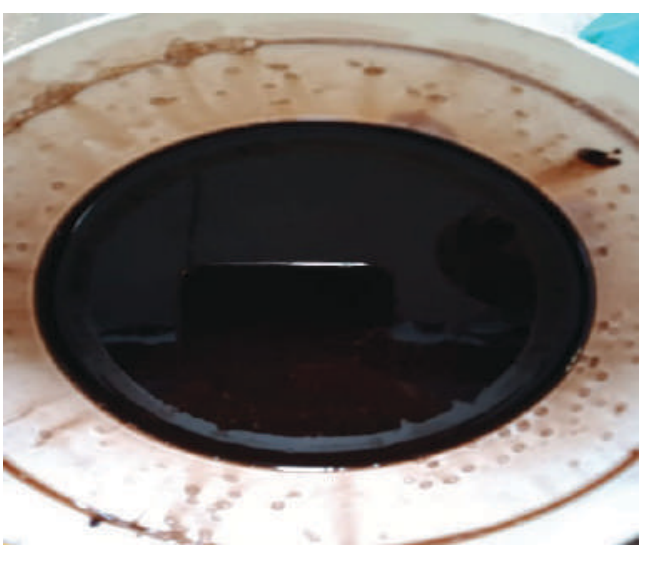

Gambar 4. Pupuk Cair berbahan dasar limbah organik rumah tangga dengan bioaktivator EM4

Tahapan terakhir adalah evaluasi yang dilakukan pada 23Oktober 2019. Padatahapini,pengabdimendengarkan pertanyaan dari anggota KWT terkait proses fermentasi pupuk kompos. Pengabdi juga menjawab pertanyaan dan memberikan saran bagi anggota KWT untuk melanjutkan kegiatan pembuatan pupuk kompos berbahan dasar limbah organik rumah tangga. Anggota KWT merasa senang bisa dilatih membuat pupuk kompos karena ini sejalan dengan program desa mereka yakni menjadi kampung tematik yang diberi nama "Kampung Rosella". Dengan demikian, anggota KWT dapat membuat sendiri pupuk organik untuk mendukung pertumbuhan tanaman Rosella.

Anggota KWT Nila 4A, KWT Nila 6E, dan KWT Lahan Hijau tidak hanya diberi keterampilan membuat pupuk kompos. Pengabdi juga memberikan pengetahuan kepada peserta untuk memproduksi pupuk kompos berbahan dasar limbah organik rumah tangga secara berkelanjutan. Dalam hal ini, peserta tidak hanya 
mengandalkan sayuran limbah rumah tangga dari anggota, melainkan bisa mengambil limbah sayuran di pasar. Hal ini karena lokasi tempat tinggal dan sekretariat KWT sangat dekat jaraknya dengan pasar tradisional di desa tersebut.

Pupuk kompos yang dihasilkan nantinya bisa terdapat dalam dua jenis, padat dan cair. Untuk pupuk kompos padat dapat dikemas dalam karung sebelum dijual, sedangkan pupuk kompos cair dikemas dalam botol plastik ukuran 1 liter.

\section{SIMPULAN}

Adapun simpulan yang dapat diambil usai dilaksanakannya pengabdian kepada masyarakat ini adalah Anggota Kelompok Wanita Tani (KWT) Nila 4A, KWT Nila 6E, dan KWT Lahan Hijau di RT. 4 Kelurahan Sumber Jaya Kecamatan Kampung Melayu Kota Bengkulu sudah mampu membuat pupuk kompos berbahan dasar limbah organik rumah tangga dengan biokativator EM4.

\section{DAFTAR PUSTAKA}

Darmawati. (2015). Efektivitas Berbagai Bioaktivator Terhadap Pembentukan Kompos dari Limbah Sayur dan Daun. Jurnal Dinamika Pertanian Volume XXX Nomor 2: 93-100.

Dahruji, Pipit F., \& Totok H. (2017). Studi Pengelolahan Limbah Usaha Mandiri Rumah Tangga dan Dampak Bagi Kesehatan di Wilayah Kenjeran. Jurnal Aksiologiya. 1 (1), 36-44.

Nunik, E., \& Arini.A. (2018). Pengomposan sampah Organik (Kubis dan Kulit Pisang) dengan Menggunakan EM4. TEDC, 12
(1), 38-43.

Pandebesie ES \& Rayuanti D. (2013). Pengaruh Penambahan Sekam Pada Proses Pengomposan Sampah Domestik. Jurnal Lingkungan Tropis. 6(1): 3140.

Putri, N., Wayan., \& Made Sudarma. (2016). Kinerja Pengelolaan Limbah Hotel Peserta Proper dan Non Proper di Kabupaten Bandung, Provinsi Bali. Ecotrophic. 10 (1), 33-40.

Sahwan, F., L., Wahyono, S., dan F. Suryanto. (2011). Kualitas Kompos Sampah Rumah Tangga yang Dibuat Dengan Menggunakan "Komposter" Aerobik. Jurnal Teknologi Lingkungan Volume 12 Nomor 3: 233-240.

Santoso AB.(2015). Pengaruh luas lahan dan pupuk bersubsidi terhadap produksi padi nasional. $J$ Ilmu Pertan Indones. 20(3):208-212.

Suwatanti \& widiyaningrum. (2017). Pemanfaatan MOL limbah Sayur pada Proses Pembuatan Kompos. Jurnal MIPA, 40 (1), 1-6.

Waluyo, L. (2010). Teknik Dasar Metode Mikrobiologi.UMM Press. Malang

Wihardjaka, A. (2018). Penerapan Model Pertanian Ramah Lingkungan Sebagai Jaminan Perbaikan Kuantitas dan Kualitas Hasil Tanaman Pangan. Jurnalpangan.com. Dikases 16 Juli 2019. 